\title{
Is Ethics Education Necessary? A Comparative Study Of Moral Cognizance In Taiwan And The United States
}

\author{
Chiulien C. Venezia, Frostburg State University, USA \\ Gerald Venezia, Geovalue Consultants, USA \\ Frank J. Cavico, Nova Southeastern University, USA \\ Bahaudin G. Mujtaba, Nova Southeastern University, USA
}

\begin{abstract}
Ethical development, cognizance, and maturity, as well as ethical behavior, are a primary concern of all managers, government officials, and educators. These moral values are even more important in Asian economies where some aspects of the economy seem to "go underground" without any due taxation afforded to the government or proper credit accorded to the property owners or copyright or other intellectual property holders. This article examines morality and ethics from a cross-cultural perspective. The article examines works using Kohlberg's Cognitive Moral Development theory and the Defining Issues Test (DIT), in order to ascertain the moral cognizance of workers and students, with particular attention to the variables of age, education, ethics education, and gender. United States samples are compared with studies of Taiwanese managers and Taiwanese students. The purpose was to see if there is relationship between any of these variables and moral maturity and cognizance, as well as whether any of these relationships were culturally influenced.
\end{abstract}

Keywords: Ethical Development; Cognizance; Cognitive Moral Development; Defining Issues Test; Ethics Education

\section{INTRODUCTION}

\section{Ethics and Moral Development}

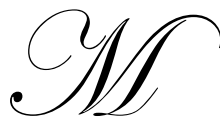

oral development, according to Mujtaba (1997), is the growth of a person's ability to distinguish right from wrong, to develop a system of ethical values, and to learn to act morally. The term development refers to progressive and continuous changes from the beginning of life until the end. Moral development occurs through the process of not only maturity, but also socialization as a person acquires an education, grows older, and obtains management experience (Mujtaba et al, 2009). Mujtaba (2010) also states that moral development occurs through the process of socialization, education, aging, and experience. Each individual has the ability to think about his or her own thought process, which is known as "self-awareness." It is the "selfawareness" ability which enables people to make significant advances from generation to generation (Mujtaba, 2010, 1997).

It is believed that science, religion, culture, standards of good and bad, and other forms of behavior in society are passed on by nurture (that is, they are learned) and not by nature. The authors believe that each individual has the ability to think about his or her own thought process, which is known as "self-awareness." Moral character is an aspect of personality, which can structure a person's moral, ethical, and personal beliefs. In general, a person may be deemed moral when he or she behaves ethically. Moral behavior appears to be a function of one's past experience with similar situations in which a person has learned to behave morally. Social and moral potentialities may be nourished best through brain development between birth and maturity, supplemented by the process of education. Moral learning, accordingly, is not much different from any other form of learning. Society 
influences behavior of its members through education and experience as people grow older. Accordingly, people with higher levels of formal education and more experience should be more morally aware (Mujtaba et al, 2009), one would assume. One principal purpose of this work, therefore, is to discern if education, ethics education, and ethics training relate to morality and ethics. That is, does the education level of a person, including particularly ethics education and ethics training, relate to that person's moral maturity and business ethics?

Is there a relationship between ethics and morality? That is, is there a relationship between education and moral maturity, and business ethics? Furthermore, is there a relationship between specifically ethics education and/or ethics training and the aforementioned variables? Most business schools today have mandatory courses on business ethics on the undergraduate as well as graduate level. Moreover, corporations have such courses too, as well as business ethics training and also diversity and sensitivity training. Furthermore, most companies today have codes of ethics or codes of conduct, as well as concomitant ethics code communication, education, and training. Do all or any of these extensive education efforts affect the moral maturity, moral cognizance, and moral behavior of people?

Ethics is the theoretical study of morality. Ethical theories are moral philosophical undertakings that contain bodies of formal, systematic, and ethical principles that are committed to the view that an asserted ethical theory can determine how one should morally think and act. Moral judgments are deducible from a hierarchy of ethical principles. It is the moral philosopher's task to articulate such ethical principles and to insist upon their proper application. Ethics is the sustained and reasoned attempt to determine what is morally right or wrong. Ethics is used to test the moral correctness of beliefs, practices, and rules. Ethics necessarily involves an effort both to define what is meant by morality and to justify the way of acting and living that is being advocated. Ethics proceeds from a conviction that moral disagreements and conflicts are resolvable rationally. There is one "right" answer to any moral dispute, and this answer can be reached through reasoning. The purpose of ethics is to develop, articulate, and justify principles and techniques that can be used in specific situations where a moral determination must be made about a particular action or practice (Cavico and Mujtaba, 2009). One ethical theory, very relevant in today's global economy and marketplace, is the theory of ethical relativism which bases moral determinations on what a society believes is moral. "When in Rome, do as the Romans," counsel the ethical relativists. When one first ascertains what the pertinent society is (which may be challenging in a heterogeneous society), one "merely" has to find out what the relevant moral norms and precepts are in that culture; and when one does, one needs to simply conform to the current prevailing cultural moral norms, and then one will be acting morally, at least in that society. So, if it is considered to be morally acceptable to bribe foreign officials in a particular society in order to secure a contract for one's firm, then by all mean bribe, as that is the moral thing to do. Of course, obviously, pursuant to this ethical theory, there can be no universal ethical norms; ethics and morality are just relative.

Values are rankings or priorities that a person establishes for one's norms and beliefs; they are ordered by relative importance. Values express what the chief end of life is, the highest good, and what things in life are worthwhile or desirable. Deeply held values drive behavior. One very difficult problem is placing values in proper relation to one another. Values often are controversial because the norms and beliefs that one person holds in high esteem conflict with different norms and beliefs that another person holds in equally high esteem. Values are acquired through childhood experiences, education, and learning from one's ancestors; and this social learning supplies one's norms and values, which are an important part of one's culture and the customs of that culture (Huang, 2006). Moral values are the rankings or priorities that a person establishes for one's moral norms and moral beliefs (Cavico and Mujtaba, 2009). Huang (2006) states, that "the value system has a strong effect on what is perceived as right or wrong" (p. 16). Making moral rules and moral judgments based on ethical reasoning from ethical principles and ranking values accordingly are highly intellectual exercises, and, as shall be seen in the forthcoming discussion of moral cognizance, indicate that a person has a high degree of moral development and maturity.

In Western philosophy there are two main "modern" ethical theories - Utilitarianism, based on the writings of the English philosophers and social reformers, Jeremy Bentham and John Stuart Mill; and Immanuel Kant. These two philosophical schools of thought are diametrically opposed to one another causing dilemmas for anyone wishing to behave in an ethical manner. The Utilitarian principle holds that morality is determined by an action that produces "the greatest amount of good for the greatest number of people." It is also egalitarian in that it treats everyone as an 
equal in counting everyone's pleasure and pain since people are all human beings. Consequently, an action may produce more overall good, and thus be moral, yet still cause pain to a minority; nonetheless the action overall is moral. Kant, however, was confounded by such a moral conclusion; he thought it morally reprehensible that an ethical theory could morally legitimize pain and suffering. Kant therefore declared that in determining morality, the first step one must take is to disregard the consequences of an action; rather, one must analyze the action itself to make sure it passes the supreme Kantian test for morality - the Categorical Imperative, which demands that an action to be moral must treat people with dignity and respect and as worthwhile human beings and must neither demean nor disrespect people or treat them as "means" as opposed to "ends" in themselves. According to Kantian ethics, therefore, even if an action produces more overall good, if it disrespects anyone it is immoral. Of course, the authors would counsel students, employees, managers, and leaders to look for the action that produces the greater good for the person, the organization, and society, but without demeaning or disrespecting anyone in the process of achieving this good (Cavico and Mujtaba, 2009). These ethical theories are, of course, Western-based theories, and thus most likely part of the philosophical framework as well as decision-making process of most Western managers. Yet Singhapakdi, et al (2000) warn that a "common problem faced by international researchers is the need to apply theories developed in one country in other countries. It is possible that available ethics theories therefore, could be too oriented toward the American business context. Given that culture plays an important role in influencing ethical decision-making...not focusing more on the ethical decision-making process of managers from non-U.S. cultures, may result in an incomplete understanding of...ethics" (p. 272).

It is incumbent on the U.S. academic, researcher, and business person studying or doing business overseas to be cognizant of other philosophical and ethical approaches. The predominant Chinese philosophical school of thought found throughout East and Southeast Asia today is Confucianism. Confucianism's "main concern was to cultivate the living humanity of the individual and society in harmony, according to the way of the ideal course of moral conduct" (Venezia, 2004, p. 27). Virtuous behavior will bring about individual success and social harmony (Huang, 2006). Ames (2009) has stated that the Confucian perspective has two dimensions which have ramifications for global business people and managers: 1) the homogenization of knowledge, processes, and skills that enable people to accomplish things and enhance the quality of their life and 2) mutual accommodation of different cultures (Ames 2009).

Although this study uses a Western based theory, we felt it was appropriate to outline the differences between Euro-American philosophical moral thought and East Asian Chinese morality that might explain later results in this comparative study.

\section{Cognitive Moral Development}

Kohlberg's model is based on three levels of morality, each subdivided into two stages for a total of six stages of moral reasoning. The construct is based on "justice" as the foundation of morality. Kohlberg's theory of moral development hypothesized that individuals move sequentially from stage to stage in a unidirectional progress from lower to higher levels of morality. He assumes the moral philosophy position of Kant, in particular likening stage six reasoning to Kant's Categorical Imperative, especially, the universal moral law principle, in which one logically reasons to the moral law and imposes the moral law on oneself. Kohlberg developed the Moral Judgment Interview (MIJ) as a device to assess and individual's cognitive moral development. In his original instrument, the test-taker was presented with three moral dilemmas. Each situation dealt with a value conflict that tested the participant's moral reasoning. Respondents were persuaded to discuss their responses and to provide an explanation of what he or she believed was the ethical action of choice. The goal of the MJI was to determine the reasoning behind the respondent's ethical choice (Cavico and Mujtaba, 2009).

\section{Kholberg, Rest, and the Defining Issues Test}

Kholberg's work was followed by that of James Rest (1941-1999), who concurred with the majority of Kohlberg's theory. However, unlike Kohlberg, Rest purported that individuals could use a combination of a variety of moral reasoning capabilities simultaneously. Rest took exception to the major theories of moral development including the cognitive-development, the social learning, the psychoanalytical, or social psychology's approach. Rest believed that each of theories was faulty because of their limited focus on some particular aspects of moral 
thinking; and they consequently failed to develop a more "holistic" composite of morality. In response, he developed a four part model of the major component processes involved in making moral decision. Rest and his colleagues at the University of Minnesota proposed a four-component composite paradigm of ethical decisionmaking. Rest held that moral behavior is the manifestation of four intercognitive-affective processes. Distinctive cognitions and affects are involved in each of the processes. They are as follows:

Component One: To interpret the situation in terms of how one's actions affect the welfare of others. The facet involves empathizing with the other parties involved in any situation and weighing the consequences of actions.

Component Two: To determine what action would best meet a particular moral ideal; that is, what ought to be done. This component involves two schools of thought. The first is that social norms govern how a moral course of action is to be defined. The second tradition is the cognitive-development approach. Here, the focus is on the rationale for establishing cooperative agreements and how each of the participants in cooperation are reciprocating and mutually benefiting.

Component Three: To decide what one actually intends to do by selecting among competing values. This facet involves the process of choosing what action to pursue and recognizing that each action represents potentially competing motives.

Component Four: To execute and implement what one intends to do. This facet involves persisting along a course of action in spite of obstacles.

Unlike Kohlberg, Rest's component structure is not a stair-step, linear, decision-making model. While Kohlberg asserted that individuals proceed through his Cognitive Moral Development model in one direction, Rest held that each factor had an effect on other factors, creating a complicated web of cognitive decision-making. James Rest termed the ability to think in a principled manner, "fairness judgment" (Cavico and Mujtaba, 2009).

From Kohlberg's six stages of moral judgment, Rest developed the Defining Issues Test (DIT) in 1974. Originally published in Developmental Psychology, the DIT measured the level of one's moral development and the reasons behind an individual's moral decisions. One of the differences between Kohlberg's research and that of the DIT can be found in the data collection methodology. Kohlberg used a qualitative method to collect his research; a painstaking process often taking hours of interview time for each test taker. Rest developed a quantitative method to analyze moral reasoning and to discover a person's level of moral maturity based on the Kohlberg scale. While both Kohlberg and Rest employed the ethical dilemma methodology comprised of stories of individuals facing moral challenges, Rest's quantitative test is a self-administered pen-and-pencil test that can completed in approximately 25-35 minutes. The DIT presents a series of scenarios and offers the test-taker with solutions based on different rationales. Even though two individuals may arrive at the same response, their reasoning may reflect substantial differences in moral development and levels of critical thinking. These scenarios and responses represent deepseated, underpinnings of social thought, instead of the fine descriptions of specific concepts and ideas. Reasons for the decision are scored according to Kohlberg's stages of moral development (Cavico and Mujtaba, 2009).

Cognitive Moral Development, by definition, is related to increased intellectual capacity, which is certainly related to education (Reid, 2004). As Bateman (1998) noted, "historically, education has had two goals: to help people become smart and to also to help them to become good" (p. 52). So, one can logically assume that there is a positive relationship between education and moral maturity. A great deal of research has been conducted to ascertain if education in fact affects the moral maturity and moral cognizance of people. Most of the research has determined that education does have a positive effect on the moral development and morality of individuals and the education does help reach a higher level of moral development (Mujtaba, 1996, pp. 21-22).

Building on the theory of moral development, one principal purpose of this study is to determine whether education, age, or ethical training is related to ethical decision-making. 


\section{METHODOLOGY}

The authors reviewed the literature on the DIT studies and chose a series of researches to broaden the scope of this study. Secondary data collected from those studies were analyzed to determine whether age, management experience, education, or gender of a person relate to that person's moral cognizance or moral maturity; that is, does the ability to make moral determinations based on reasoning from ethical theories and principles relate to any of the preceding factors? The following researchers sought to discern their participant's moral cognizance/maturity on Lawrence Kohlberg's moral cognizance scale pursuant to James Rest's Defining Issues Test (DIT), which assigns a "P" morality score ("P" for "principled") person who makes moral decisions based on reasoning from ethical theories and principles (Cavico and Mujtaba, 2009). Drumm (2002) noted that “...a DIT P score above 50 means that an individual is conceptualizing the moral issues in the same manner that moral philosophers conceptualize problems and moral dilemmas" (p.68).

The Defining Issues Studies: Age, Gender, Management Experience, Education, and Ethics Education Variables and Moral Cognizance

The first set of studies focused on student populations in the United States of America. The researchers (see Table 1) included Sandra Bateman (1996), Kevin Buell (2009), Carol Cannon (2001), Evelyn Cartwright (2006), Melissa Hickman (2008), and Donna Galla (2006).

Table 1

\begin{tabular}{|c|c|c|c|c|c|}
\hline Name & Ethics Education & Gender & Age & Education & $\begin{array}{c}\text { Work } \\
\text { Experience }\end{array}$ \\
\hline $\begin{array}{l}\text { Bateman, } \\
\text { Sandra }\end{array}$ & & & & $\begin{array}{l}\text { Graduate students } \\
\text { scored higher than } \\
\text { undergraduate } \\
\text { students }\end{array}$ & \\
\hline $\begin{array}{l}\text { Buell, } \\
\text { Kevin }\end{array}$ & \begin{tabular}{l}
\multicolumn{2}{l}{ Inverse Score } \\
Ethics $\quad p=26.63$ \\
No Ethics $p=32.91$
\end{tabular} & $\begin{array}{l}\text { No Significant } \\
\text { difference }\end{array}$ & & & \\
\hline $\begin{array}{l}\text { Cannon, } \\
\text { Carol }\end{array}$ & No significant difference & & $\begin{array}{l}\text { Working adults over } \\
36 \text { years of age } \\
\text { scored higher than } \\
\text { those under } 36\end{array}$ & $\begin{array}{l}\text { Graduate students } \\
\text { scored higher than } \\
\text { undergraduate } \\
\text { students }\end{array}$ & $\begin{array}{l}\text { No } \\
\text { significant } \\
\text { difference }\end{array}$ \\
\hline $\begin{array}{l}\text { Cartwright, } \\
\text { Evelyn }\end{array}$ & $\begin{array}{l}\text { Those who had taken } 3 \\
\text { courses scored higher than } \\
\text { those who had taken none }\end{array}$ & $\begin{array}{l}\text { F. } p=25.25 \\
\text { M. } p=21.51 \\
\text { A significant } \\
\text { difference }\end{array}$ & & $\begin{array}{l}\text { Undergraduate } \\
\text { seniors scored } \\
\text { higher }\end{array}$ & \\
\hline $\begin{array}{l}\text { Hickman, } \\
\text { Melissa }\end{array}$ & $\begin{array}{l}\text { No significant difference } \\
\text { between those who had } \\
\text { taken and those who had } \\
\text { not taken an ethics course }\end{array}$ & $\begin{array}{l}\text { F. } p=26.46 \\
\text { M. } p=23.04 \\
\text { A significant } \\
\text { difference }\end{array}$ & $\begin{array}{l}\text { A correlation } \\
\text { between age and } \\
\text { moral reasoning }\end{array}$ & & \\
\hline $\begin{array}{l}\text { Galla, } \\
\text { Donna }\end{array}$ & No significant difference & $\begin{array}{l}\text { F. } p=24.06 \\
\text { M. } p=22.87 \\
\text { No significant } \\
\text { difference }\end{array}$ & $\begin{array}{l}\text { No significant } \\
\text { difference }\end{array}$ & $\begin{array}{l}\text { No significant } \\
\text { difference }\end{array}$ & \\
\hline
\end{tabular}

Kevin Buell (Beull, 2009) examined the relationship between ethics education and the moral reasoning of undergraduates and graduate accounting students. Beull's ethics education research questions (p.5) were as follows" "Is there a relationship between the moral maturity level of different groups of accounting students and the variable of ethics education? That is, is there a difference in moral maturity level...between accounting students who have had ethics courses and accounting students who have not had ethics courses?'The results of Buell's study demonstrated a significant relationship existed between ethics education and the moral reasoning of the students. However, the results were not in the anticipated direction; rather, there was an inverse relationship; that is, the 
students without ethics education had higher moral cognizance scores on the DIT. He concluded by stating that the results of his study..."demonstrate the complexity of behavioral ethics in general, and the linkage between ethical judgment and ethical action in particular" (Buell, 2009, p.65).

Melissa Hickman (2008), Donna Galla (2006), and Carol Cannon (2001) on the other hand found no significant difference in their studies when it came to ethics education. In so far as age was concerned, Carol Cannon's study revealed that working adults over the age of 36 scored higher than those younger. Melissa Hickman and Donna Galla showed no difference.

Their studies did confirm Kohlberg's CMD theory that higher levels of formal education will predict higher moral development (Cannon, 2001, p.97). Three of the studies revealed that scores increased exponentially with education.

The following six studies focus on private sector employees in the United States of America (Table 2), including researchers Joseph Chavez (2003), William Freeman (2007), Thomas Heron (2007), William Joseph Kennedy (2003), James Reichl (2009), and Pamela Smith Evans (2004).

Table 2

\begin{tabular}{|c|c|c|c|}
\hline Name & Education & Ethics Education & Ethics Training \\
\hline Chavez, Joseph & $\begin{array}{l}\text { College degree } \quad p=28.65 \\
\text { No College degree } \\
p=27.65 \\
\text { No significant difference }\end{array}$ & No difference & \\
\hline Freeman, William & $\begin{array}{l}\text { Significant difference between } \\
\text { all levels of education }\end{array}$ & & \\
\hline Heron, Thomas & $\begin{array}{l}\text { Four year college students } \\
\text { scored slightly higher than } \\
\text { community college } \\
\text { No significant difference }\end{array}$ & & $\begin{array}{l}\text { Inverse scoring } \\
\text { Ethics Training } \quad \mathrm{p}=32.28 \\
\text { No Ethics Training } \mathrm{p}=36.58\end{array}$ \\
\hline Kennedy,William Joseph & $\begin{array}{l}\text { Significant difference between } \\
\text { all levels of education }\end{array}$ & & $\begin{array}{l}\text { Significant difference in one of } \\
\text { five industries; a private } \\
\text { insurance company }\end{array}$ \\
\hline Reischl, James & $\begin{array}{l}\text { Architects } \quad \mathrm{p}=36.4 \\
\text { Contractors } \quad \mathrm{p}=34.06 \\
\text { Suppliers } \quad \mathrm{p}=27.65 \\
\text { No significance between } \\
\text { Architects and Contractors. } \\
\text { Suppliers determined as being } \\
\text { in a different grouping }\end{array}$ & & \\
\hline Smith Evans, Pamela & $\begin{array}{l}\text { Significant difference between } \\
\text { African-Americans with formal } \\
\text { education }\end{array}$ & & No significant difference \\
\hline
\end{tabular}

Researchers in this group examined three variables in relation to Kohlberg and Rest; education, ethics education, and ethics training. Many studies point to the first variable, education as having a strong, positive, and predictive relationship with ethics, especially with Kohlberg's levels of Cognitive Moral Development as ascertained by Rest's Defining Issues Test (DIT) (Freeman, 2007). Neubaum et al (2009) asserted that “...college education has been shown to be a powerful experience in the moral development of all students, including those from the business school" (p.20).

Chavez (2003) attempted to ascertain whether education had any positive relationship to the moral maturity of banking employees using Kohlberg's scale and the DIT-1 survey. He asked, "Is there a relationship between moral maturity level and banking employees with post-secondary education and banking employees without postsecondary education"? His results revealed that participants with college degrees did have higher P-scores than participants without college degrees but not enough to indicate a significant difference. Chavez (2003) also 
attempted to ascertain whether ethics education and/or training had any positive relationship to the moral maturity. $\mathrm{He}$ answered this question in the negative as the P-scores of the two groups were very similar; and thus he stated that it made no difference whether participants had ethics courses and/or training.

Freeman (2007) studied the cognitive moral development of managers in "knowledge management" firms with those in non-"knowledge management' firms using the DIT-1 survey. One of his questions was designed to ascertain if there was a relationship between the education level of the managers and moral maturity. Freeman's (2007) research indicated that there was a positive significant statistical relationship between all levels of education (vocational and technical school, high school, college, graduate school, and professional school) and moral maturity.

Heron (2007) examined the cognitive moral development of Information Technology (IT) professionals; including programmers, analysts, product and service support staff, project managers, and database administrators using the DIT-2. His posited the question whether a difference existed between IT professionals with a formal education level of a high school degree, a 2-year junior or community college degree, a master's level graduate degree, or a doctoral level graduate degree? His results indicated that respondents with a four-year college or university degree had a higher mean P-score than those respondents with a two year, junior or community college degree, but that the difference was not statistically significant (Heron, 2007, p. 130). Concerning the ethics training variable, the results proved of interest. His results indicated that the mean moral maturity P-score for those IT professionals reporting ethics training was 32.28 as opposed to a mean score of 36.58 for those not reporting ethics training (p. 125), thereby revealing an inverse relationship between the variable of ethics training and moral maturity.

Kennedy's (2003) research led him to examine "leaders" (executives, managers, and administrators) in the banking, insurance, and computer industries along with a military command. He found a positive difference in moral judgment by educational level of the leaders he surveyed (Kennedy, 2003, pp. 71-72). Kennedy (2003) also sought to determine if the presence of ethics training was reflected in the participant's ethical maturity scores. He found that only within a private insurance company was there a positive significant relationship between the amount of ethic training received by the leaders and their moral maturity levels (Kennedy, 2003, pp. 72-73).

Reischl's (2009) analysis of the moral maturity of architects, contractors, and suppliers in the construction industry led him to conclude that education is the principal moderating variable for moral maturity. In his sample, the architects clearly had higher education levels than contractors and suppliers, and the contractors had higher education levels than suppliers (Reischl, 2009, p.133). His results indicated that the architects in fact had the higher P-scores, followed by contractors and suppliers.

Smith Evans (2004) investigated the ethical maturity of African-American business professionals, as well as members of the National Black Master of Business Administration organization. Among other variables, she sought to determine if level of education influenced their ethical maturity levels. Her study indicated that there was a difference in the ethical maturity level between groups of formally educated African-American business professionals (Smith Evans, 2004, p. 76). In addition to the education variable, she sought to ascertain if ethics training resulted in higher moral maturity scores. She questioned whether this is a difference in ethical maturity level between different groups of African-American business professionals with formal ethics training? Although she found that there was a positive relationship between morality and education generally, Smith Evans (2004) found "... no difference in ethical maturity level between groups of African-American business professionals with formal ethics training" (p. 77).

Students and private sector professionals in the United States of America were the focus of the first two sets of studies. In contrast, the last set of studies turned its attention to the nation of Taiwan. Taiwan, a Confucian culture, was included (Table 3) to compare whether two cultures so different showed any difference in ethical maturity using the DIT survey. Two researchers were selected to illustrate our comparable study - Venezia (2004) and Huang (2006). 
Table 3

\begin{tabular}{|c|c|c|c|c|c|}
\hline Name & Age & Education & Ethics Training & Gender & $\begin{array}{c}\text { Work } \\
\text { Experience }\end{array}$ \\
\hline Venezia, Chiulien C. & $\begin{array}{l}\text { No significant } \\
\text { difference }\end{array}$ & $\begin{array}{l}\text { Graduate } \mathrm{p}=31.22 \\
\text { Undergraduate } \mathrm{p}=29.41\end{array}$ & $\begin{array}{l}\text { No significant } \\
\text { difference }\end{array}$ & $\begin{array}{l}\text { F. } P=31.74 \\
\text { M. } P=26.41 \\
\text { Significant } \\
\text { difference }\end{array}$ & \\
\hline Huang, Chunlong & $\begin{array}{l}\text { No significant } \\
\text { difference }\end{array}$ & $\begin{array}{l}\text { No significant } \\
\text { difference }\end{array}$ & $\begin{array}{l}\text { No significant } \\
\text { difference }\end{array}$ & $\begin{array}{l}\text { No significant } \\
\text { difference }\end{array}$ & $\begin{array}{l}\text { No significant } \\
\text { difference }\end{array}$ \\
\hline
\end{tabular}

Venezia (2004) performed a cross-cultural comparable study of accounting students in the United States of American and Taiwan. Her primary research objective was to ascertain if Taiwanese accounting students possess the same ethical reasoning levels compared to U.S. accounting students. She examined numerous variables including age, education, ethics training, and gender. Venezia (2004) found that age had no significant difference in the ethical reasoning abilities of accounting students in the U.S. and in Taiwan. The results were the same for ethics training. In light of the Enron and other accounting scandals, accounting programs have placed a greater emphasis on ethics in their curricula. She noted, however, that the research is decidedly mixed as to whether such ethics education, whether general business ethics and/or accounting ethics, as well as ethics integration, improve the accounting student's level of ethical reasoning. Her education research question was as follows: "Is there a difference in the level of ethical reasoning abilities by education level of accounting students (pp. 7, 47)? Her results indicated that the higher education level graduate accounting and auditing students did in fact have higher P-scores with a mean of 31.22 than the undergraduate students who had a mean of 29.41 , but that the results were not statistically significant (pp. 91-92).

Where Venezia (2004) did find a difference was with gender. Venezia's (2004) review of the gender and cognizance literature pointed to females as demonstrating higher levels of moral reasoning abilities than males (p. 41). Her gender research results showed that the mean $P$ score was 26.41 for male and 31.74 for female accounting students (Venezia, 2004, p. 82). She concluded that there was a significant difference between male and female accounting students and that the female students had significantly higher moral cognizance than the male students.

Huang (2006) also conducted a cross-cultural examination of moral maturity levels. In his study he focused on U.S. and Japanese expatriate managers in Taiwan as well as Taiwanese manager who worked for Taiwanese based multinational corporations. Huang (2006) tested for age, education, gender, and management experience. His test results showed no significant difference with any variable.

\section{SUMMARY AND CONCLUSION}

\section{Implications of the DIT Studies}

The Cognitive Moral Development theory posits that as a person increases in age, his or her capability and level of moral reasoning should concomitantly and progressively increase too (Mujtaba 2010). Furthermore, as a person increases in age, so does the complexity of the moral questions that a person will confront; and accordingly, moral reasoning should increase with age (Mujtaba and Cavico, 2009; Mujtaba et al., 2009). Perhaps a combination with education would demonstrate a stronger link to moral maturity than between "mere" age and moral maturity (Mobley, 2002, p.74; Mujtaba, 1996, p. 24). The researchers reviewed here demonstrate that the variable age showed no significant difference. Out of five studies, three found no relationship between age and moral maturity. On the question of formal education, the results were mixed; although split evenly, four out of the six studies that identified no significant difference actually demonstrated that those participants with formal education scored higher moral reasoning than those who had less formal education, but that the results were not statistically different enough to warrant answering in the positive.

However, perhaps contrary to expectations, the dissertations also indicated that ethics education and/or training did not relate positively to moral development and cognizance. Seven of the eleven researchers indicated that there was no benefit from ethical education or ethical training, but most surprising were the two studies that 
showed an inverse score. Buell (2009) and Heron's (2007) studies present a conundrum; why does education generally appear to be a correlating variable to morality in the context herein, but specifically ethics education and ethics training do not? What is "wrong" with ethics education and ethics training for them not to influence morality in a positive way, and indeed, in two cases, in negative fashion?

The literature on gender and ethics is as mixed as the results of this study. Some of the past researchers report that gender does not affect the moral reasoning of individuals (Jadack et al., 1995; Pratt, Golding \& Hunter, 1998). However, others conclude that males and females pass through different stages of moral development at different age categories. Gilligan (1982) claims that while males are learning rules as part of their moral development, females are learning about intimacy, caring, helping, and relationships. The results of the dissertations reviewed for this study was split evenly; six researchers found a correlation and six did not.

\section{Recommendations}

Neubaum et al (2009) counsel that "before introducing curriculum reform, we believe business schools need to develop a much fuller picture of why their students - the future managers of the work - make unethical decisions" (p. 20). According to Rest, education is the strongest correlate to and predictor of cognitive moral development and ethical maturity (Huang, 2006, p. 56; Hyppolite, 2003, p. 137; Mobley, 2002, p. 74).

Ethics education is certainly a growing concern today. Yet why should colleges and universities teach business ethics? Does providing ethics education to students, especially business students, show up in their enhanced moral maturity levels or moral conduct? Are such ethics courses effective in promoting morality? Assuming that ethics education is very important and relevant today, what should be taught, and how should ethics be taught?

Buell (2009) explained: "Many institutions rely upon structured lectures. This approach relies on imparting information followed by discussion. Other approaches by institutions include understanding ethical concepts and reasoning by themselves...Following this approach, exercises are employed to clarify and justify student beliefs and personal reflections. Another common approach to teaching business ethics has been the analysis of management case studies, which provides for active dissection of ethical judgments and their fall-outs in legal, business, and cultural contexts...Another common techniques utilized in business ethics education in undergraduate and graduate business departments include offering courses that analyze the scandals of companies such as Enron, WorldCom, and Health South. Avoiding the duplication of similar scandals is the goal of such pedagogy" (pp. 67-68). Bateman (1999) noted that "one model is a normative approach based in philosophy" (p.48).

Certain researchers state that business ethics is not a course to be taught (Wolfe, 1993). Wolfe (1993), for example, asserts that business ethics is rather more of a moral system that needs to be examined throughout the entire educational process. He also states that it is equally important that business students learn to be socially responsible in the business environment (Wolfe 1993). Actually, Wolfe (1993) recommends that the course in business ethics should be called "The Study of Corporate and Professional Social Responsibility."

Ethics is a subject matter - technically a branch of philosophy - which can be taught and trained like any other subject matter. True, ethics education and training may not guarantee moral behavior, but at the very least such education and training will create a cognizance of moral issues, and most importantly, a concomitant awareness that immoral conduct will not be tolerated in the organization, the community, and society as a whole.

\section{CONCLUSION}

The research was designed to determine whether work experience, education, age, gender, and management experience gained through the maturation continuum or process, are related to moral maturity, ethical decisionmaking, and business ethics.

Today there is an economic crisis and business is blamed, in part, and perhaps mainly for the financial collapse. Have business people become so consumed with the single-minded pursuit of seemingly obscene profits that the values of legality, morality, and social responsibility have been traduced? Perhaps some business leaders 
have become so obsessed. Have they forgotten that free enterprise and capitalism cannot be conducted, they cannot survive, and consequently society cannot prosper unless business is based on a solid foundation of transparency, legality, morality, and ethics? Ethics is essential to capitalism, as there is not enough law, precise and exact and allencompassing law, as well as lawyers and government regulators, to govern business. Business schools, therefore, must take every measure to ensure that they are fulfilling their moral duty to their students, the business community, and society as a whole by integrating ethics into the business student's education. Yet, ultimately, ethical standards and moral conduct must come from within business people. Business managers, executives, entrepreneurs, and especially leaders must have a "moral compass"; that is, they must have a moral sense and ethical judgment as well as the moral character and integrity to do what they know is the right thing to do and not do what they know is wrong. They thus must self-regulate themselves; otherwise they are asking for even more government regulation, including even more draconian criminal laws. Yet ultimately, for capitalism to survive and prosper, for economic growth to be restored and to flourish, and for the U.S. and global economies to be healed and functioning well once again, the commitment to morality and ethics on the part of business people was never more critical.

\section{AUTHOR INFORMATION}

Chiulien C. Venezia, DBA, CPA, is an assistant professor of Accounting at Frostburg State University. She taught at Southern Taiwan University for twelve years before coming to Frostburg State University. Her areas of research are cross- cultural ethics, accounting behavior, and financial performance.

Gerald Venezia, DPA has taught at universities and colleges in Taiwan and the United States. His area of research ranges from administrative ethics, international relations and globalization.

Frank J. Cavico is a professor of Business Law and Ethics at the H. Wayne Huizenga School of Business and Entrepreneurship of Nova Southeastern University. Professor Cavico holds a J.D. degree from St. Mary's University School of Law and a B.A. from Gettysburg College. He also possesses a Master of Laws degree from the University of San Diego - School of Law and a Master's degree in Political Science from Drew University.

Bahaudin G. Mujtaba, D.B.A., is Department Chair and an Associate Professor of Management and Human Resources. His areas of research are ethics, higher education assessment, leadership, faculty training, and diversity management.

\section{REFERENCES}

1. Ames, Roger T. (2009). Confucian Moral Imagination and the Global Condition: Knowledge and Ethics Must Go Together. Humanities Public Forum II Lecture at the Institute of International Studies of Ramkhamhaeng University. August 18, 2009, 9:30 am - 12:00 pm, at the IIS Building, Bangkok, Thailand.

2. Bateman, Joann Sandra (1998). Ethical Dilemma Survey of Undergraduate and Graduate Students. Doctoral Dissertation. The H. Wayne Huizenga School of Business and Entrepreneurship. Nova Southeastern University.

3. Buell, Kevin E. (2009). The Relationship of Ethics Education to the Moral Development of Accounting Students. Doctoral Dissertation. The H. Wayne Huizenga School of Business Administration. Nova Southeastern University.

4. Cannon, Carol (2001). Does Education Increase Moral Development? A Re-examination of the Moral Reasoning Abilities of Working Adult Learners. Doctoral Dissertation. The H. Wayne Huizenga School of Business and Entrepreneurship. Nova Southeastern University.

5. Cartwright, Evelyn (2006). The Relationship between Ethics and Ethnicity: An Examination of Moral Cognizance and Moral Decision-making in a Diverse Student Population. Doctoral Dissertation. The H. Wayne Huizenga School of Business and Entrepreneurship, Nova Southeastern University.

6. Cavico, F. J. and Mujtaba, B. G. (2009). Business Ethics: The Moral Foundation of Leadership, Management, and Entrepreneurship ( $2^{\text {nd }}$ edition). Pearson Custom Publications. Boston, United States.

7. Chavez, Joseph (2003). Morality and Moral Reasoning in the Banking Industry: An Ethical and Cognitive Moral Development Examination. Doctoral Dissertation. The H. Wayne Huizenga School of Business and Entrepreneurship. Nova Southeastern University. 
8. Drumn, Michael H. (2002). The Ethical and Moral Development Difference of Municipal Department Heads Based on the Defining Issues Test. Doctoral Dissertation. The H. Wayne Huizenga School of Business and Entrepreneurship. Nova Southeastern University.

9. Freeman, William J. (2007). Moral Maturity and the Knowledge Management Firm. Doctoral Dissertation. The H. Wayne Huizenga School of Business and Entrepreneurship. Nova Southeastern University.

10. Galla, Donna (2006). Moral Reasoning of Finance and Accounting Professionals: An Ethical and Cognitive Moral Development Examination. Doctoral Dissertation. The H. Wayne Huizenga School of Business and Entrepreneurship. Nova Southeastern University.

11. Heron, W. Thomas (2006). An Examination of the Moral Development and Ethical Decision-making of Information Technology Professionals. Doctoral Dissertation. The H. Wayne Huizenga School of Business and Entrepreneurship. Nova Southeastern University.

12. Hickman, Melissa S. (2008). Religiosity and Ethical Reasoning in Accounting Students. Doctoral Dissertation. The H. Wayne Huizenga School of Business and Entrepreneurship. Nova Southeastern University.

13. Huang, Chunlong (2006). Cross-Cultural Ethics: A Study of Cognitive Moral Development and Moral Maturity of U.S. and Japanese Expatriate Managers in Taiwan and Taiwanese Managers. Doctoral Dissertation. The H. Wayne Huizenga School of Business and Entrepreneurship. Nova Southeastern University.

14. Hyppolite, Aranck Aurel (2003). The Influence of Organizational Culture, Ethical Views and Practices in Local Government: A Cognitive Moral Development Study. Doctoral Dissertation. The H. Wayne Huizenga School of Business and Entrepreneurship. Nova Southeastern University.

15. Jadek, R. A., Hyde, J.S., Moore, C. F., and Keller, M.L. (1995) Moral reasoning about sexually Transmitted diseases. Child Development, 66, 167-177.

16. Kennedy, William Joseph (2003). A Study of the Moral Reasoning Skills of Proactive and Reactive Organizational Management. Doctoral Dissertation. The H. Wayne Huizenga School of Business and Entrepreneurship. Nova Southeastern University.

17. Mobley, Sandra E. Ford (2002). The Study of Lawrence Kohlberg's Stages of Moral Development Theory and Ethics: Considerations in Public Administration Practices. Doctoral Dissertation. The H. Wayne Huizenga School of Business and Entrepreneurship. Nova Southeastern University.

18. Mujtaba, B. G. (1997). Business Ethics Survey of Supermarket Managers and Employees. UMI Dissertation Service. A Bell \& Howell Company. UMI Number: 9717687.

19. Mujtaba, Bahaudin G., Cavico, Frank J., McCartney, Timothy O., and DiPaolo, Peter T. (2009). Ethics and Retail Management Professionals: An Examination of Age, Education, and Experience Variables.

American Journal of Business Education, Vol. 2, No.3, pp. 13-25

20. Mujtaba, Bahaudin G. (2010). Business Ethics of Retail Employees - How Ethical are Modern Workers? A Study of Morality based on Gender, Age, Education, and Management Experience. Davie, Florida: ILEAD Academy LLC.

21. Neubaum, Donald O., Pagell, Mark, Drexler, John A. Jr., McKee-Ryan, and Larson, Erik (2009). Business Education and Its Relationship to Student Personal Moral Philosophies and Attitudes Toward Profits: An Empirical Response to Critics. Academy of Management Learning \& Education, Volume 8, Number 1, pp. 9-24.

22. Pratt, W.M., Golding G., and Hunter, W. (1988). "From Inquiry to Judgment: Age and Sex Difference in Patterns of Adult Moral Thinking and Information-Seeking. International Journal of Aging and Human Development, 272(2), pp. 109-124.

23. Reischl, , James N. (2009). Toward a Theory of Morality: An Empirical Study of Cognitive Moral Development in Market Channel Dyads in the Construction Industry Using the Defining Issues Test. Doctoral Dissertation. The H. Wayne Huizenga School of Business and Entrepreneurship, Nova Southeastern University.

24. Reid, Maise E. (2004). An Empirical Examination of Organization Ethical Climate and the Cognitive Moral Development of Health Care Professionals. Doctoral Dissertation. The H. Wayne Huizenga School of Business and Entrepreneurship, Nova Southeastern University.

25. Singhapakdi, Anusorm, Salyachivain, Somboom, Virakul, Buscaya, and Veeerayangkur, Vinch (2000). Some Important Factors Underlying Ethical Decision Making of Managers in Thailand. Journal of Business Ethics, 27, pp. 271-284. 
26. Smith Evans, Pamela K. (2004). A Study of Cognitive Moral Development Theory and Moral Maturity of African-American Business Professionals. Doctoral Dissertation. The H. Wayne Huizenga School of Business and Entrepreneurship, Nova Southeastern University.

27. Venezia, Chiulien Chuang (2004). The Ethical Reasoning Abilities of Accounting Students: Comparison between the U.S. and Taiwan. Doctoral Dissertation. The H. Wayne Huizenga School of Business and Entrepreneurship, Nova Southeastern University

28. Wolfe, A. (1993). We've had enough business ethics. Business Horizons, pp. 1-3.

\section{NOTES}

